\title{
SEBARAN DAN HUBUNGAN PARAMETER REPRODUKSI IKAN TUNA MADIDIHANG (Thunnus albacares) DENGAN SUHU DAN KLOROFIL-a DI LAUT BANDA
}

\section{REPRODUCTIVE PARAMETER OF YELLOWFIN TUNA (Thunnus albacares) DISTRIBUTION AND RELATIONSHIP WITH TEMPERATURE AND CHLOROPHYLL-a IN BANDA SEA}

\author{
Karsono Wagiyo, Ali Suman dan Mufti Petala Patria \\ Balai Penelitian Perikanan Laut, Muara Baru-Jakarta \\ Teregistrasi I tanggal: 27 Agustus 2015; Diterima setelah perbaikan tanggal: 26 November 2015; \\ Disetujui terbit tanggal: 30 November 2015 \\ e-mail :k_giyo@yahoo.co.id
}

\begin{abstract}
ABSTRAK
Laut Banda diketahui mempunyai kondisi lingkungan yang mendukung sebagai daerah pemijahan ikan tuna madidihang (Thunnus albacares). Sebaran parameter reproduksi dan hubungannya dengan lingkungan perlu diketahui sebagai dasar pengelolaan sumberdaya yang lestari. Penelitian dilakukan tahun 2011-2012 dengan basis pendataan di Bandaneira. Pengamatan parameter reproduksi dilakukan terhadap ikan sampel melalui observasi dan enumerasi. Suhu dan klorofil-a diperoleh dari analisis citra satelit. Penelitian mendapatkan persentase gonad matang $(100 \%)$ dan indeks kematangan gonad tertinggi $(3,75)$ serta nisbah kelamin seimbang, secara temporal ditemukan pada bulan antara September-Desember, secara spasial ditemukan di Perairan Gunung Api dan Selatan Kepulauan Lease. Tingkat kematangan gonad dan indeks kematangan gonad meningkat terjadi pada saat suhu mulai menghangat dan klorofil-a mulai menurun. Tingkat kematangan gonad dan indeks kematangan gonad menurun terjadi pada saat awal penurunan suhu dan awal kenaikan klorofil-a.
\end{abstract}

KATA KUNCI: Ikan tuna madidihang, parameter reproduksi, suhu, klorofil-a dan Laut Banda

\section{ABSTARCT}

Besides known as the Banda Sea region yellowfin tuna migration (Thunnus albacares) is also a spawning area. Distribution of Reproduction parameter and their relationship with environmental parameter should be known as the basis for sustainable resource management. The reproduction parameter obtaianed by observation and enumeration. Temperature and chlorophyll-a obtained by satellite image analysis. Research gets a high percentage of the gonads mature (100\%) and gonad maturity index (3,75) and a balanced sex ratio, temporally be found in the September-December, spatially found in the waters of Pulau Gunung Api and Lease Islands. The maturity level of gonads and gonadal maturation index increases occurred when the temperatures begin to warm and chlorophyll-a start to decline. The maturity level of gonads and gonadal maturation index decreases occurred at the beginning of the early drop in temperature and increase in chlorophyll-a.

KEYWORDS: Yellowfin tuna, reproductive parameter, temperature, chlorophyll-a and Banda Sea.

\section{PENDAHULUAN}

Secara ekologis Laut Banda merupakan daerah ruaya, asuhan, pemangsaan dan pemijahan ikan tuna madidihang. Kondisi ini didukung oleh letak Laut Banda yang merupakan pertukaran masa air dunia, sesuai pernyataan Gordon (2005) bahwa Laut Banda mempunyai karakteristik tropis, oseanik, bersifat oligotropik yang dikellingi oleh ekosistem terumbu karang, tempat terjadinya umbalan (up welling) dan pertemuan masa air.

Secara sosial ekonomi Laut Banda telah ditetapkan sebagai kawasan segitiga emas lumbung ikan nasional (KKP 2011.b.; Listriana, 2011). Sumberdaya utama yang mendukung lumbung ikan Laut Banda adalah adanya stok

Korespondensi penulis:

Balai Penelitian Perikanan Laut-Muara Baru, Jakarta

Jl. Muara Baru Ujung, Komp. PPS Nizam Zachman-Jakarta Utara ikan tuna madidihang (Thunnus albacares). Oleh karena ikan tuna madidihang bersifat peruaya jauh melintasi berbagai wilayah laut, maka sumberdaya ikan tuna di Laut Banda merupakan satok bersama antar negara.

Pemanfaatann sumberdaya ikan tuna madidihang secara industri di Laut Banda dilakukan secara intensif semenjak adanya Banda Sea Agreement pada tahun 19681975 (Marten, 1982). Selain skala industri, pemanfaatan secara tradisional dilakukan oleh masyarakat di sekitarnya sebagai sumber matapencaharian. Dampak dari pemanfaatan intensif, pada saat sekarang kondisi sumberdaya ikan tuna madidihang di Laut Banda mencapai fully exploited (KKP 2011.a.). Kondisi ini menunjukkan bahwa sumberdaya ikan tuna madidihang di Laut Banda memerlukan pengelolaan agar tetap lestari. 
Penerapan pengelolaan memerlukan data dasar mengenai parameter reproduksi dan parameter lingkungan ikan tuna madidihang di Laut Banda. Penelitian parameter reproduksi antara lain oleh Itano (2000), Stequert et al. (2001), Mardlijah (2008) dan Andamari et al. (2012). Penelitian parameter lingkungan Laut Banda antara lain oleh Zijstra \& Baars (1990) mengenai arus, Gordon \& Ffield (1994) mengenai pengenceran masa air dan Larrouy (2007) mengenai transformasi masa air. Data dan informasi hubungan parameter reproduksi dengan parameter lingkungan sangat diperlukan dalam pengelolaan sumberdaya ikan tuna madidihang yang lestari, sehingga pada penelitian ini bertujuan untuk mengetahui sebaran spasial dan temporal tingkat kematangan gonad, indeks kematangan gonad, nisbah kelamin dan hubungannya dengan suhu dan klorofil-a.

\section{BAHANDANMETODE \\ Lokasi dan Waktu Penelitian}

Pendataan parameter reproduksi dilakukan di Banda Neira, sebagai tempat pendaratan ikan tuna madidihang yang tertangkap di perairan sekitar Kepulauan Banda. Lokasi penangkapan ikan dibedakan menjadi empat area yaitu; Area Timur Laut, Area Tenggara, Area Barat Daya dan Area Barat Laut dengan pusat sumbu pada koordinat $129^{\circ} .50^{\prime \prime} .00^{\prime}$ BT/04 $.40^{\prime \prime} .00^{\prime}$ LS (Gambar 1). Pembagian area dimungkinkan karena adanya perbedaan karkteristik perairan masing-masing area yang didasarkan dari berbagai literatur; Wyrtki (1961) adanya pengaruh empat musim, Zijstra \& Baars (1990) mengenai arus, Gordon \& Ffield (1994) mengenai pengenceran masa air, Gordon \& Susanto (2001) mengenai devergensi masa air Laut Banda, Gordon (2005) mengenai upwelling dan Larrouy (2007) mengenai transformasi masa air. Waktu pengambilan data parameter reproduksi dan lingkungan pada tahun 20112012.

\section{Pengambilan Data}

Pengambilan data parameter reproduksi meliputi, tingkat kematangan gonad (TKG), indeks kematangan gonad (IKG) dan nisbah kelamin dilakukan secara observasi dan enumerasi harian terhadap ikan tuna madidihang yang didaratkan dengan pancing ulur (749 ekor). Untuk mengetahui sebaran spasial, daerah asal ikan tertangkap (fishing ground) di catat dan dikelompokan dalam masing-masing area. Area Timur Laut meliputi Burang, Pulau Pisang, Pohong dan Digor. Area Tenggara meliputi Pulau Hatta, Uring dan Skaru. Area Barat Daya meliputi Kalapa, Lonthor, Nama dan Noret. Area Barat Laut meliputi Selatan Kepulauan Lease, Pulau Run, Manukang, Line Kapal, Pulau Ai dan Gunung Api. Untuk mengetahui sebaran temporal data harian dikelompokan menjadi bulanan. Data suhu dan klorofil-a, diperoleh dengan mengunduh data bulanan citra satelit tahun 2011-2012 dan dianalisis dengan Aqua MODIS level 3.

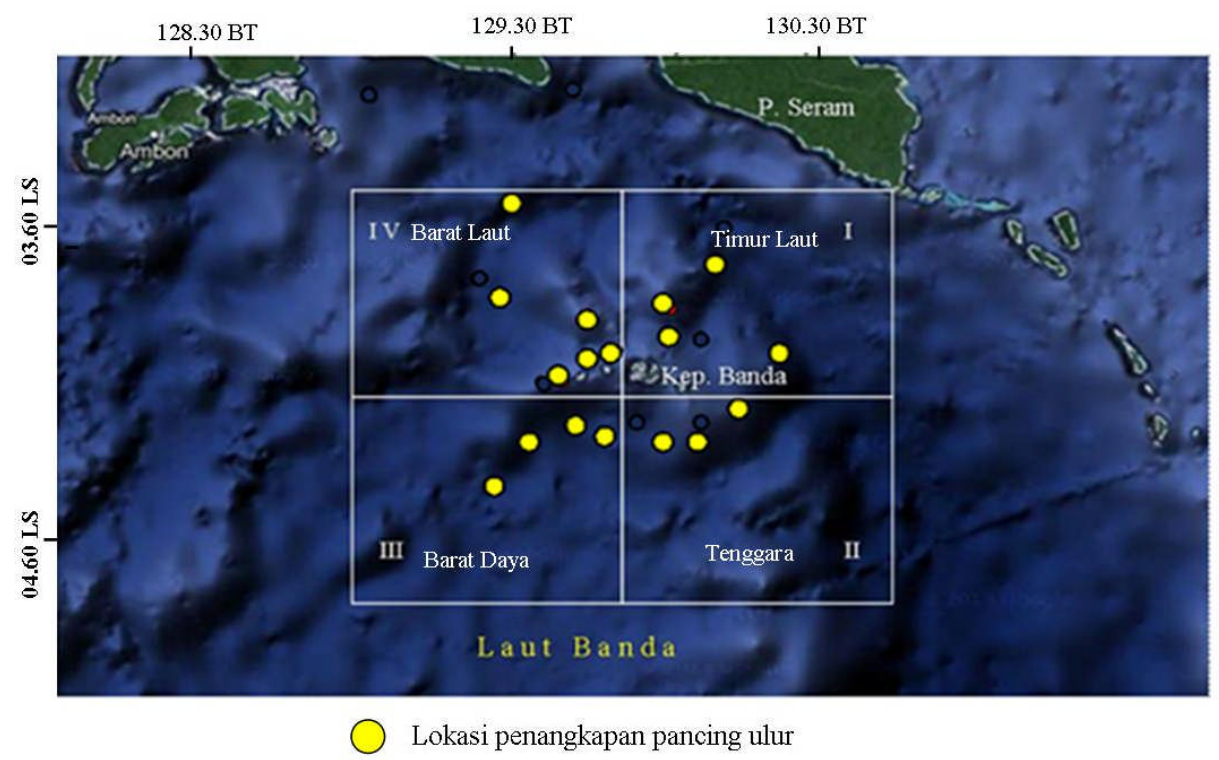

Gambar 1. Lokasi Penelitian di Banda Neira.

Figure 1. Research location in Banda Neira.

\section{Pengolahan danAnalisa data}

Data indeks kematangan gonad mengikuti cara Zudaire et al. (2010) dan Effendi (1997) dengan persamaan :
$G S I=\frac{G w}{T w} X 100$

GSI = indeks kematangan,

$\mathrm{Gw}=$ berat gonad $(\mathrm{g})$,

$\mathrm{Tw}=$ beratikan $(\mathrm{g})$. 
Tingkat kematangan gonad diperoleh menurut panduan dari Schaefer \& Orange (1956) dan Matsumoto \& Miyabe (2002). Data tingkat kematangan dibedakan gonad matang (TKG III \&IV), gonad belum matang (I \& II) dan spent/salin (TKG V). Unit data tingkat kematangan gonad dalam persentase.

Nisbah kelamin diperoleh dengan memperbandingkan antara jumlah ekor ikan jantan dan jumlah ekor ikan betina, dengan persamaan :

$\mathrm{X}=\mathrm{M}: \mathrm{F} ;$

Keterangan:

$\mathrm{X}=$ nisbah kelamin,

$\mathrm{M}=$ jumlah ikan jantan (ekor),

$\mathrm{F}=$ Jumlah ikan betina (ekor).

Untuk menentukan keseimbangan nisbah kelamin dilanjutkan dengan uji khi-kuadrat (Steel \& Torrie 1989) dengan persamaan sebagai berikut :

$X^{2}=\sum \frac{{\text { (Frekuensi teramati - Frekuensi harapan })^{2}}_{\text {Frekuensi harapan }}}{\text {. }}$
Analisa sebaran temporal parameter reproduksi didasarkan pada data bulanan. Analisa sebaran spasial didasarkan pada data per lokasi. Analisis hubungan parameter reproduksi (TKGdan IKG) dengan grafikal.

\section{HASIL DAN BAHASAN \\ Hasil}

\section{Tingkat Kematangan Gonad (TKG)}

Pengamatan TKG ikan tuna madidihang selama tahun 2011 menunjukkan pada bulan Juni dan Juli mempunyai persentase gonad matang rendah. Di tahun yang sama puncak gonad matang terjadi pada bulan Oktober, November dan Desember, ditunjukkan dengan seluruh ikan tuna madidihang tercacah dalam keadaan matang gonad. Persentase gonad spent tertinggi dijumpai pada bulan Desember sebesar 12,50 \%. Pengamatan pada tahun 2012 di bulan Juni dan Juli masih menunjukkan persentase gonad matang rendah, tetapi terendah terjadi pada bulan Februari $(33,33 \%)$. Puncak gonad matang kembali terjadi pada bulan Oktober dan November, tetapi dibandingkan dengan tahun 2011 persentase gonad matang menurun, masing-masing adalah $97,85 \%$ dan $92,8 \%$ (Gambar 2.).



Gambar 2. Distribusi bulanan tingkat kematangan gonad ikan tuna madidihang di Laut Banda.

Figure 2. Monthly gonad maturity distribution of yellowfin tuna in Banda sea.

Sebaran TKG menurut lokasi, pada seluruh lokasi dijumpai gonad matang, hanya persentase yang berbedabeda. Gonad matang $100 \%$ dijumpai di lokasi penangkapan Selatan Kepulauan Lease, Gunung Api, dan Skaru (Gambar 3). Gonad spent dijumpai di lokasi P. Run $(0,5 \%)$, Line Kapal $(1,52 \%)$, Burang $(1,67 \%)$ dan P.Hatta $(1,85 \%)$. Persentase gonad matang terendah dijumpai pada lokasi penangkapan Kalapa $(72,22 \%)$ dan Lonthor $(66,67 \%)$. Sebaran secara area persentase gonad matang dijumpai di area Tenggara dan Barat Laut, masing-masing sebesar $87,86 \%$ dan $87,88 \%$.

\section{Indeks Kematangan Gonad (IKG)}

Sebaran IKG rata-rata, ikan tuna madidihang secara bulanan, tertinggi terjadi pada bulan September, masing- masing untuk tahun 2011 dan 2012 sebesar 1,83 dan 1,72 (Gambar 4). IKG terkecil terjadi pada bulan Januari dan Februari tahun 2012 masing-masing sebesar 0,15 dan 0,12. IKG terbesar 3,75 terjadi pada bulan September tahun 2011, Oktober dan November tahun 2012.

Sebaran menurut lokasi IKG rata-rata tertinggi dijumpai pada perairan sekitar Pulau Gunung Api sebesar 2,41 dan rata-rata terkecil $(1,09)$ dijumpai di P. Pisang. IKG secara individu tertinggi sebesar 3,75 dijumpai di Selatan Kepulauan Lease, Manukang dan Burang (Gambar 5). IKG terkecil dijumpai di P. Run $(0,12)$ dan P. Hatta $(0,19)$. Sebaran IKG ikan tuna madidihang menurut area, rata-rata tertinggi dijumpai 1,52 di area Barat Laut sebesar 1,52. 




Gambar 3. Sebaran tingkat kematangan gonad ikan tuna madidihang per lokasi penangkapan dan per area.

Figure 3. Gonads maturity distribution of yellowfin tuna by catch location and area.

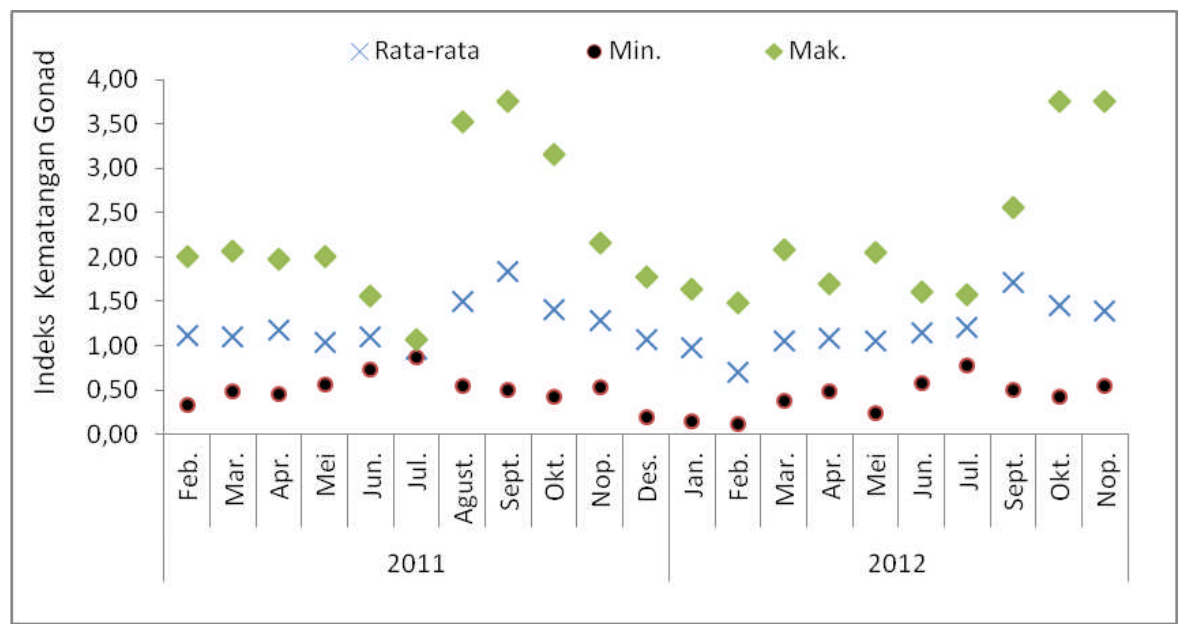

Gambar 4. Sebaran indeks kematangan gonad ikan tuna madidihang per bulan.

Figure 4. Gonads maturity index of yellowfin tuna by month .

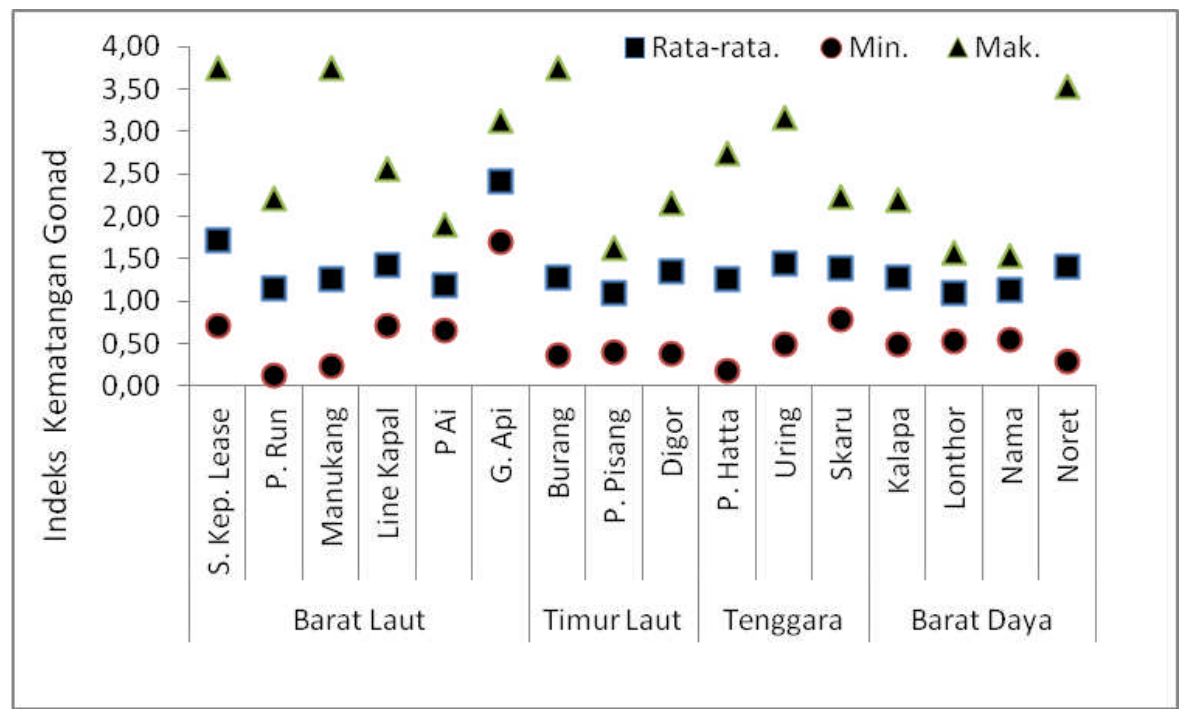

Gambar 5. Sebaran indeks kematangan gonad ikan tuna madidihang di Laut Banda per lokasi.

Figure 5. Goonad maturity index of yellowfin tuna in Banda sea by location. 


\section{Nisbah Kelamin}

Sebaran nisbah kelamin ikan tuna madidihang di Laut Banda secara bulanan tercantum pada Gambar 6 . Pengamatan pada tahun 2011 dijumpai variasi nisbah kelamin bulanan ikan tuna madidihang pada umumnya lebih seimbang dibandingkan pada tahun 2012. Pada periode ke dua tahun, jantan lebih dominan dibandingkan betina, kecuali pada bulan Februari 2011 ikan betina (51,02 $\%)$ lebih besar dari jantan $(48,98 \%)$.
Sebaran nisbah kelamin menurut lokasi pada tahun 2011, jantan lebih dominan. Betina dominan hanya dijumpai pada tiga lokasi antara lain Digor, Skaru dan Selatan Kepulauan Lease. Pada tahun 2012, nisbah kelamin setiap bulannya didominasi oleh jantan. Nisbah kelamin seimbang dijumpai di perairan Pulau Pisang, Skaru dan Pulau Gunung Api (Gambar 7). Nisbah kelamin menurut area, Area Barat Laut dan Tenggara memiliki rasio betina dan jantan yang lebih berimbang dibandingkan area lainnya.

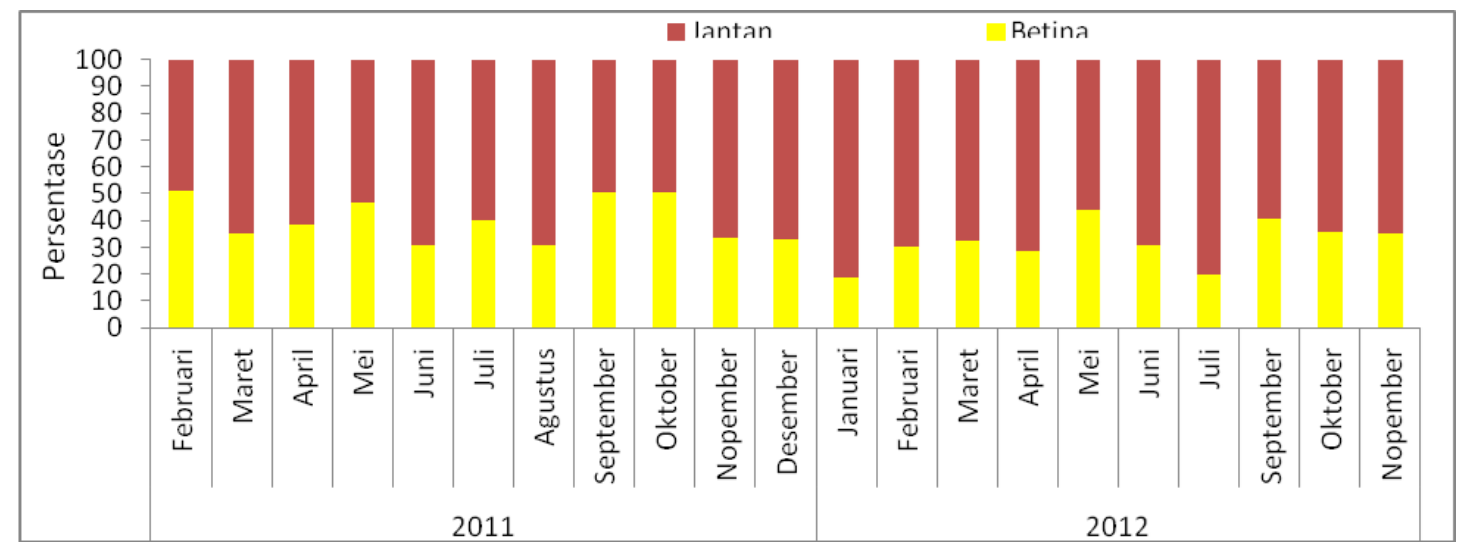

Gambar 6. Sebaran nisbah kelamin ikan tuna madidihang di Laut Banda, secara bulanan.

Figure 6. Sex ratio distribution of yellowfin tuna in Banda Sea by montly.



Gambar 7. Sebaran nisbah kelamin ikan tuna madidihang di Laut Banda per lokasi.

Figure 7. Sex ratio distribution of yellowfin tuna in Banda Sea by location .

\section{Hubungan TKG dengan Suhu dan Klorofil-a Perairan}

Pada gambar 8 tertera hubungan kematangan gonad ikan tuna madidihang bulanan dengan suhu dan klorofila. Hubungan perkembangan gonad bulanan dengan suhu permukaan Laut Banda, didapatkan persentase gonad matang tinggi mencapai $100 \%$ terjadi bersamaan dengan awal kenaikan suhu air permukaan $\left(28,88-31,13^{\circ} \mathrm{C}\right)$, yaitu pada bulan Oktober, November dan Desember. Pada awal penurunan suhu air permukaan bulan Juni $\left(27,45-28,04^{\circ} \mathrm{C}\right)$, diikuti penurunan persentase gonad matang menjadi 50 $60 \%$. Pada periode suhu air hangat yang lama, terjadi persentase gonad matang terendah, yaitu pada bulan Februari sebesar 33,33\%. Hubungan kematangan gonad bulanan dengan kandungan klorofil-a perairan, kebalikan dengan suhu, persentase gonad matang tinggi terjadi bersamaan dengan penurunan kandungan klorofil-a dari puncaknya 0,3886-0,5258 ppb menjadi 0,1833-0,1908 ppb. 


\section{Hubungan IKG dengan Suhu dan Klorofil-a Perairan}

Hubungan IKG ikan tuna madidihang dengan suhu dan klorofil-a perairan Laut Banda, baik bulanan (Gambar 9) mempunyai kesamaan pola dengan TKG, yaitu IKG meningkat terjadi pada awal kenaikan suhu dan akhir kenaikan kandungan klorofil-a dan sebaliknya IKG menurun terjadi pada akhir kenaikan suhu dan awal kenaikan klorofil-a. IKG bulanan tertinggi terjadi pada bulan September $(1,84)$ terjadi pada suhu perairan 26,93æ\% C dan kandungan klorofil-a (0,4901 ppb). IKG terendah pada bulan Februari $(0,70)$ pada suhu perairan 30,52 æ\% C dan klorofil 0,1042 ppb.

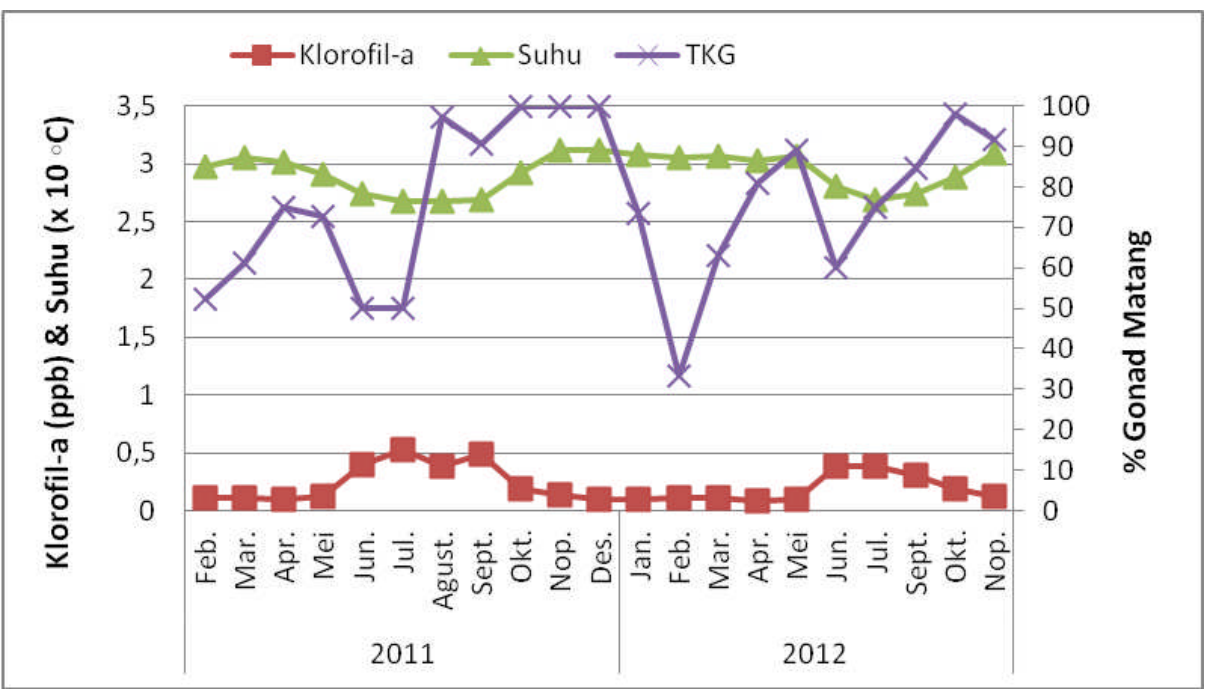

Gambar 8. Hubungan sebaran kematangan gonad ikan tuna madidihang dengan suhu dan klorofil-a.

Figure 8. Relationship the gonad maturity of yellowfin tuna with temperature and chlorophyll-a.

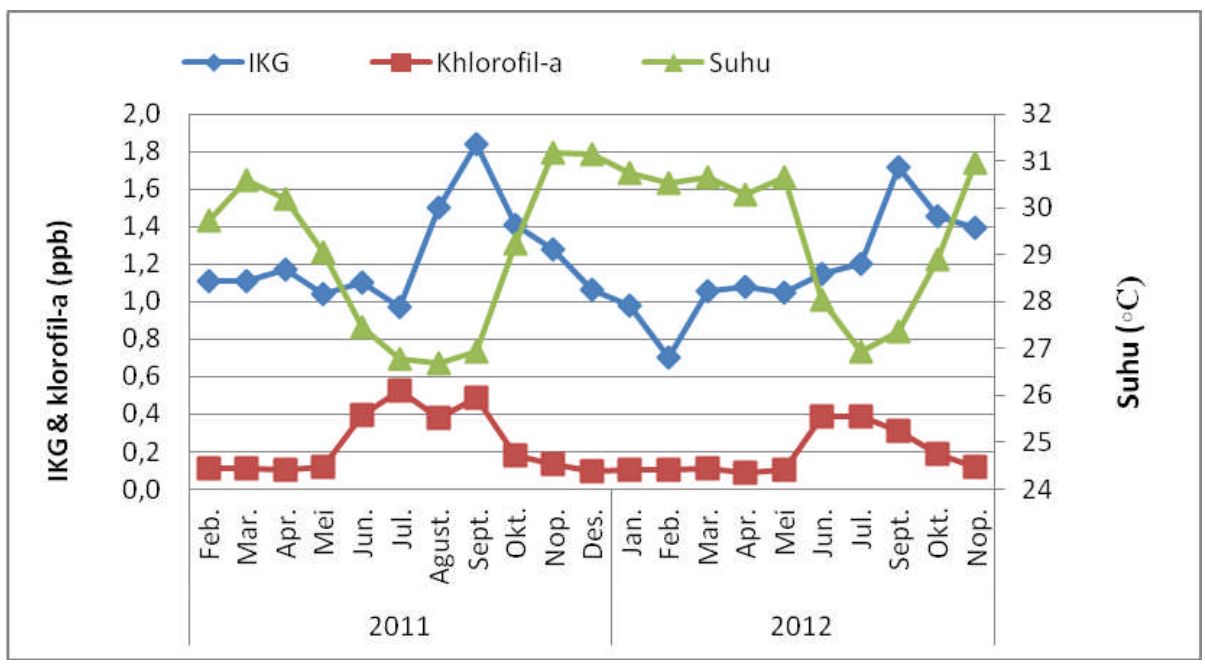

Gambar 9. Hubungan indeks kematangan gonad ikan tuna madidihang dengan suhu dan klorofil-a.

Figure 9. Relationship gonad maturity index of yellowfin tuna with temperature and chlorophyll-a.

\section{Bahasan}

\section{Sebaran Temporal Parameter Reproduksi}

Hasil pengamatan TKG ikan tuna madidihang pada tahun 2011-2012, setiap bulan ditemukan gonad matang dengan persentase gonad matang tertinggi pada OktoberDesember (Gambar 2). Pada bulan Oktober-Desember ditemukan persentase gonad salin (spent) tertinggi. Bersamaan dengan persentase matang gonad tinggi, pada saat yang sama ditemukan IKG maksimum 3,75 (Gambar 4) dan nisbah kelamin seimbang (Gambar 6).
Pencapaian IKG maksimum pada penelitian ini lebih tinggi dibandingkan dengan hasil penelitian Malok (2009) di lokasi sama, tertinggi 2,16 dan penelitian Mardlijah (2008) di Teluk Tomini tertinggi 1,7 yang dilakukan pada sekitar musim timur.

Fenomena TKG dan IKG tinggi serta nisbah kelamin seimbang berhubungan dengan musim pemijahan dan penghangatan suhu permukaan air Laut Banda. Menurut Zudaire et al. (2010), IKG diatas 1,5 menunjukkan ikan tuna madidihang siap memijah. Sun \& Yeh (1992) 
menunjukkan ikan tuna madidihang yang akan memijah mempunyai IKG 1,6. Menurut Effendi (1997) ikan yang akan memijah memiliki nisbah kelamin yang seimbang. Sumadiharga \& Hukom (1987) menemukan ikan cakalang di Laut Banda pada bulan pemijahan memiliki nisbah kelamin seimbang. Menurut Boyce et al. (2008), ikan tuna memijah bersamaan dengn saat kenaikan suhu. Gordon \& Susanto (2001) dan data BMKG Banda Neira tahun 20062011 menunjukkan saat awal kenaikan suhu permukaan air Laut Banda terjadi pada bulan Oktober-November. Menurut Itano (2000) ikan tuna madidihang di Maluku mempunyai IKG tinggi dan memijah pada bulan November. Sun et al. (2005) menemukan puncak pemijahan ikan tuna madidihang di Filipina berlangsung November-Desember. Saat puncak pemijahan yang sama, terjadi di perairan Australia (Block et al. 1977). Pengukuran klorofil-a di perairan Laut Banda pada bulan yang sama (musim peralihan II) menunjukkan tidak terlalu tinggi dan tidak terlalu rendah $(0,14 \mu \mathrm{g} / \mathrm{l})$, terendah musim Barat-Peralihan II $(0,05 \mu \mathrm{g} / \mathrm{l})$ dan tertinggi musim Timur $(1,31 \mu \mathrm{g} / \mathrm{l})$.

\section{Sebaran Spasial Parameter Reproduksi}

Gonad matang ditemukan di semua lokasi tertangkapnya ikan tuna madidihang, menunjukkan bahwa semua lokasi di Laut Banda merupakan tempat pemijahan ikan tuna madidihang. Gonad matang $100 \%$ ditemukan di P. Gunung Api, Selatan Kepulauan Lease (Gambar 3). Didukung IKG rata-rata ikan tuna madidihang pada ke dua lokasi tertinggi dibandingkan lokasi lainnya, masingmasing sebesar 2,41 dan 1,71 (Gambar 5) dan nisbah kelamin yang seimbang (Gambar 7). Lokasi ini menunjukkan pusat kosentrasi daerah pemijahan.

Fenomena bahwa semua wilayah Laut Banda merupakan daerah pemijahan dan adanya beberapa lokasi sebagai pusat pemijahan ini didukung oleh berbagai hasil penelitian. Menurut Suzuki et al. (1994) ikan tuna madidihang melakukan pemijahan secara kontinyu (sepanjang tahun) di daerah sekitar ekuator dengan garis lintang 10 N-10 S. Block et al. (1997) menunjukkan ikan tuna madidihang yang akan memijah mencari suhu hangat. Menurut Block \& Stevens (2001) ikan tuna madidihang memijah di daerah oseanik dengan paparan topografi dasar perairan yang curam. Menurut Wexler et al. (2001) larva ikan tuna madidihang melimpah di daerah sekitar Pulau dan Gunung Laut.

Pengukuran suhu pada lokasi ditemukannya TKG dan IKG tinggi didapatkan rata-rata $28,95^{\circ} \mathrm{C}$. Lokasi lain yang terendah $28,79^{\circ} \mathrm{C}$ dan yang tertinggi $29,28^{\circ} \mathrm{C}$. Pengukuran klorofil-a pada lokasi ditemukannya TKG dan IKG tinggi serta nisbah kelamin seimbang $0,19 \mu \mathrm{g} / \mathrm{l}$. Lokasi lainnya terendah 0,17 dan tertinggi $0,32 \mu \mathrm{g} / \mathrm{l}$.

\section{Hubungan Parameter Reproduksi dengan Suhu dan Klorofil-a}

Hubungan TKG dan IKG ikan tuna madidihang dengan suhu dan klorofil-a mempunyai pola yang sama (Gambar 8 dan 9). TKG dan IKG meningkat pada saat suhu mulai menghangat dan klorofil-a mulai menurun. TKG dan IKG menurun saat awal penurunan suhu dan awal kenaikan klorofil-a. TKG dan IKG terendah terjadi ditengah periode suhu perairan hangat dan klorofil-a rendah dalam jangka waktu lama. Berhubungan dengan suhu air, Block et al. (1997) menyatakan ikan tuna madidihang yang akan memijah bermigrasi mencari suhu yang lebih hangat. Orozco et al. (2000) kelimpahan tuna meningkat pada saat anomali suhu positif. Hasil penelitian ini mendapatkann peningkatan TKG dan IKG ikan madidihang terjadi bertepatan dengan Musim Peralihan II. Gordon \& Susanto (2001), setelah beberapa dekade mengamati pola fluktuasi suhu permukaan Laut Banda, mendapatkan awal penghangatan suhu perairan selalu terjadi pada Musim Peralihan II. Peranan suhu hangat dalam pematangan gonad terjadi pada ikan terbang (Ali et al. 2005) dan sidat (Herianti, 2005). Suhu hangat dapat memacu kematangan gonad karena berperan dalam (1) pembebasan GnRH pada sekresi gonadotropin dari pituitari, (2) mempengaruhi aksi gonadotropin pada produksi steroid gonad dan (3) mempengaruhi estradiol-17â pada produksi vitelogenin di dalam hepar (Kraak \& Pankhrust dalam Herianti, 2005). Pada puncak TKG dan IKG tinggi, perairan Laut Banda mempunyai suhu 29,06-29,11æ\%C dan klorofil-a 0,18330,1908 ppb. Berhubungan dengan nilai klorofil-a, ini sesuai dengan hasil penelitian Lan et al. (2012) di Laut Arabia mendapatkan hasil tangkapan ikan tuna madidihang lebih rendah pada lokasi yang mempunyai kandungan klorofila lebih tinggi. Peningkatan TKG \& IKG pada kandungan klorofil-a rendah, sesaat setelah klorofil-a tinggi, dikarenakan tersedianya mangsa yang melimpah berupa berupa ikan kecil pemangsa zooplankton grazer. Hasil penelitian Mariani et al., (2013) dan Bergkvist (2012) mendapatkan penyebab klorofil-a rendah, sesaat setelah klorofil-a tinggi adalah grazer yang melimpah.

\section{KESIMPULANDANSARAN}

Persentase gonad matang (100\%) dan indeks kematangan gonad tertinggi $(3,75)$ serta nisbah kelamin seimbang secara temporal ditemukan pada bulan antara September-Desember dan secara spasial ditemukan di Perairan Gunung Api dan Selatan Kepulauan Lease.

Penelitian mendapatkan TKG dan IKG meningkat terjadi pada saat suhu mulai menghangat dan klorofil-a mulai menurun. Kematangan gonad dan IKG menurun terjadi pada saat awal penurunan suhu dan awal kenaikan klorofil-a. 


\section{DAFTAR PUSTAKA}

Ali, S.A., M.N. Nessa, I. Djawad, Sharifuddin \& A. Djamali. 2005. Hubungan antara kematangan gonad ikan terbang (Hirundichthys oxycephalus Bleeker, 1852) dengan beberapa parameter lingkungan di Laut Flores, Sulawesi Selatan. Jurnal Ilmu Kelautan dan Perikanan Torani. (6): 403-410.

Andamari, R., J.H. Hutapea \& B.I. Prisantoso. 2012. Aspek reproduksi ikan tuna sirip kuning (Thunnus albacares). Jurnal Ilmu dan Teknologi Kelautan Tropis, 4 (1): 89-96.

Bergkvist, J. 2012. Grazer-induced responses in marine phytoplankton. Kompendiet, Aidla Trading AB, Göteborg.

Block, B.A., J.E. Keen, B. Castillo, H. Dewar, E. V. Freund, D.J. Marcinek, R.W. Brill, \& C. Farwell. 1997. Enviromental preferences of yellowfin tuna (Thunnus albacares) at the nothern extent of its range. Marine Biology. (130): 119-132.

Block, B.A., \& E.D. Stevens. 2001. Tuna: Physiology, Ecology, and Evolution. San Diego, California. Academic Press.

Boyce, D.G., D.P. Tittensor \& B. Worm. 2008. Effect of temperature on global patterns of tuna and billfish richness. Marine Ecology Progress Series. 355: $267-$ 276.

Effendie, M.I. 1997. Biologi Perikanan. Yogyakarta. Yayasan Pustaka Nusantara. 163 hal.

Gordon, A.L., \& R.D. Susanto. 2001. Banda Sea surface layer divergence. Ocean Dynamics 52: 2-10.

Gordon, A.L. 2005. Oceanography of the Indonesian Seas and their throughflow. Oceanography. 18, (4).14-27

Gordon, A.L., A. Ffield \& A.G. Ilahude. 1994. Thermocline of the Flores and Banda Seas. Journal of Geophysical Research, 99: 18235-18242.

Herianti, I. 2005. Rekayasa Lingkungan untuk memacu perkembangan ovarium sidat (Anguilla bicolor). Oseanologi dan Limnologi di Indonesia. (37): 25 41.

Itano, D.G. 2000. The Reproductive biology of yellowfin tuna (Thunnus albacares) in Hawaiian Waters and the Western Tropical Pacific Ocean:
Project Summary. SOEST 00-01 JIMAR Contribution 00328. http://www.soest.hawaii.edu/PFRP/biology/ itano/itano_yft.pdf

Kementerian Kelautan dan Perikanan. 2011a. Keputusan Menteri Kelautan dan Perikanan Republik Indonesia Nomor Kep.45/MEN/2011 tentang Estimasi Sumberdaya Ikan Di Wilayah Pengelolaan Perikanan Negara Republik Indonesia.

Kementerian Kelautan Dan Perikanan. 2011b. Lumbung Ikan Maluku Pacu Produksi Perikanan Nasional. Siaran Pers. 19/07/2011. http://www.kkp.go.id/index.php/ mobile/arsip/?category_id $=34$.

Larrouy, A.K., G. Madec, P.B. Aubertot, T. Gerkema, L. Bessieres \& R. Molcard. 2007. On the transformation of Pacific Water into Indonesian Throughflow Water by internal tidal mixing. Geophysical Research Letters, 34: L04604.

Lan, K.W., T.Nishida, M.A. Lee, H.J. Lu, H.W.Huang, S.K. Chang \& Y.C.Lan. 2012. Influence of the marine environment variability on the yellowfin tuna (Thunnus albacares) catch rate by the Taiwanese longline fishery in the Arabian sea, with special reference to the high catch in 2004. Journal of Marine science and tecnhology. 2 (5): 514-524.

Listriana, K. 2011. Kawasan Lumbung Ikan Nasional akan di Kembangkan. Bulletin Penataan Ruang Nasional. Badan Koordinasi Pemetaan Ruang Nasional. MaretApril 2011: 28-31.

Malok, Z. 2009. Beberapa Aspek Biologi ikan tuna madidihang (Thunnus albacares) yang tertangkap pada musim timur di Perairan Kepulauan Banda Maluku Tangah. Skripsi. Program Studi Manajemen Sumberdaya Perairan . Sekolah Tinggi Perikanan HattaSjahrir. Banda Naira.

Mardlijah. 2008. Analisis isi lambung dan gonad ikan madidihang (Thunnus albacares Bonnatere 1788) yang tertangkap di perairan Marisa, Gorontalo, Teluk Tomini. Tesis. Universitas Indonesia.

Mariani, P., K.H. Andersen, A.W. Visser, A.D. Barton \& T. Kiorboe. 2013. Control of plankton seasonal succession by adaptive grazing. Limnol. Oceanogr. 58(1): 173-184.

Marten, G.G., Y. Matsuda, J. Bardach, S. Comitini \& S. Hardjolukito. 1982. A Goal analysis of alternative tuna fishery arrangements between Indonesia and Japan. Ocean Management. 8: 125-150. 
Matsumoto, T., \& N. Miyabe. 2002. Preliminary report on the maturity and spawning of bigeye tuna (Thunnus obesus) in the central atlantic Ocean. Col. Vol. Sci. Pap. ICCAT. 54(1): 246-260.

Orozco, E.T., A.Trasvina, A.H. Melo \& S.O.Garcia. 2000. Variation of Yellowfin tuna (Thunnus albacares) abundance Relataed to elnino at the entrance to the Gulf of California.

Schaefer, M. B., \& C. J. Orange. 1956. Studies on sexual development and spawning of yellowfin tuna (Neothunnus macropterus) and skipjack (Katsuwonus pelamis) in three areas of the Eastern Pacific Ocean by examination of gonads. Bull.I-ATTC. 1 (6): 282-349.

Steel, G.D., \& J.H. Torrie. 1989. Prinsip dan Prosedur Statistika (Bambang Soemantri, Penerjemah). Jakarta. Gramedia. $748 \mathrm{hlm}$.

Stequert, B., J.N. Rodriguez, B. Cuisset \& F. Le Menn. 2001. Gonadsomatic index and seasonal variations of plasma sex steroids in Skipjack tuna (Katsuwonus pelamis) and yellowfin tuna (Thunnus albacares) from the western Indian ocean. Aquat. Living Resour. 14: 313-318.

Sun, C.1., W.R. Wang \& S. Yeh. 2005. Reproductive yellowfin tuna in the Central and Western Pacific
Ocean. 1 st of the Western dan Central Pacific Fisheries Commission. Noumea, New Caledonia. 8-19 August.

Suzuki, Z., 1994. A review of the biology and fisheries for yellowfin tuna (Thunnu.s albacares) in the Western and Central Pacific Ocean, (Eds.): Shomura, R. S., J. Majkowski \& S. Langi. Interactions on Pacific tuna fisheries. Volume 2 Papers on biology and fisheries. Proceedings of the First FAO Expert Consultation on interactions of Pacific Tuna Fisheries 3-11 December 1991 Noumea, New Caledonia. FAO Fisheries Technical Paper 336/2. Rome.

Wexler, J.B., D. Marqulie, S. Masuma, N. Tezuka, K. Teruya, M. Oka, M. Kanematsu \& H. Nikaido. 2001. Age Validation and growth of yellow fin tuna, Thunnus albacares larvae reared in the laboratory, in: Early life history studies of yellowfin tuna Thunnus albacares. Inter-America tropical tuna commission. Bulletin Vol. 22 No.1. La Jolla, California

Zijstra, J.J., \& M.A. Baars. 1990. Productivity and fisheries potensial of the Banda Sea ecosystem. Netherlands Journal of Sea Research Chapter. 5:54-65.

Zudaire, I. H. Murua, M, Grande, M. Korta, H. Arrizabalaga, J. Areso, \& A.D. Molina. 2010. Reproductive biology of yellowfin tuna (Thunnus albacares) in the Western and Central Indian Ocean. IOTC-2010-WPTT-48. 